\title{
Topoisomerase II
}

National Cancer Institute

\section{Source}

National Cancer Institute. Topoisomerase II. NCI Thesaurus. Code C18434.

Topoisomerase II catalyzes relaxation of supercoiled DNA molecules, catenation, decatenation, knotting, and unknotting of circular DNA. The topoisomerase II reaction appears to involve crossing-over of two DNA segments. Human cells contain two topoisomerase II isozymes: alpha and beta from distinct genes. DNA topoisomerase II alpha is associated with the Pol II holoenzyme and is required for chromatin-dependent co-activation. Transcription results in superhelical tension; topoisomerase II relaxation activity is essential for productive RNA synthesis on nucleosomal DNA. (from OMIM 126430 and $\mathrm{NCl}$ ) 